University of Nebraska - Lincoln

DigitalCommons@University of Nebraska - Lincoln

Nutrition and Health Sciences -- Faculty

Publications

Nutrition and Health Sciences, Department of

2017

Nonprofit Pay in a Competitive Market: Wage Penalty or

Premium?

Christian King

University of Nebraska-Lincoln, Christian.King@ucf.edu

Gregory B. Lewis

Georgia State University, glewis@gsu.edu

Follow this and additional works at: https://digitalcommons.unl.edu/nutritionfacpub

Part of the Benefits and Compensation Commons, Business Administration, Management, and Operations Commons, Health and Medical Administration Commons, Human and Clinical Nutrition Commons, Labor Relations Commons, Molecular, Genetic, and Biochemical Nutrition Commons, Nonprofit Administration and Management Commons, Nursing Administration Commons, Other Nutrition Commons, and the Public Affairs, Public Policy and Public Administration Commons

King, Christian and Lewis, Gregory B., "Nonprofit Pay in a Competitive Market: Wage Penalty or Premium?" (2017). Nutrition and Health Sciences -- Faculty Publications. 98.

https://digitalcommons.unl.edu/nutritionfacpub/98

This Article is brought to you for free and open access by the Nutrition and Health Sciences, Department of at DigitalCommons@University of Nebraska - Lincoln. It has been accepted for inclusion in Nutrition and Health Sciences -- Faculty Publications by an authorized administrator of DigitalCommons@University of Nebraska Lincoln. 


\title{
Nonprofit Pay in a Competitive Market: Wage Penalty or Premium?
}

\author{
Christian King ${ }^{1}$ and Gregory B. Lewis ${ }^{2}$ \\ 1 University of Nebraska-Lincoln, Lincoln, NE, USA \\ 2 Georgia State University, Atlanta, GA, USA
}

Corresponding author - Christian King, Department of Nutrition and Health Sciences, University of Nebraska-Lincoln, 104I Ruth Leverton Hall, Lincoln, NE 68583, USA; email cking7@unl.edu

\begin{abstract}
Two competing theories argue that the nonprofit sector pays differently: Nonprofit employees may accept lower pay to be able to do meaningful work for a good cause, or they may earn higher pay due to nonprofit organizations' tax exemptions and weaker incentives to hold down wages. To test these opposing expectations, we use the 2005-2013 American Community Surveys to examine pay differences among registered nurses working for nonprofit, for-profit, and public hospitals. We also test hypotheses that public and nonprofit hospitals have smaller pay disparities by gender, race, and relationship status. We find that pay is highest in nonprofit hospitals, partly because they attract better-educated and more experienced nurses, but partly because they pay comparable nurses more than for-profit hospitals do. Furthermore, contrary to expectations, pay disparities appear to be largest in nonprofit hospitals.
\end{abstract}

Keywords: wage inequality, registered nurses, nonprofit and for-profit comparison, selection, hospital

\section{Introduction}

Competing theories predict different pay patterns in nonprofit organizations. The donative labor theory argues that employees of the nonprofit sector earn less than they would in the for-profit sector, because they choose to accept lower pay in exchange for more meaningful work (e.g., Rose-Ackerman, 1996). Typically, this means that they are furthering a cause that they believe in, but they 
may also be choosing work they find intrinsically motivating for other reasons. Nonprofits may even choose to pay below-market rates to help them select the most motivated workers (Benz, 2005; Borzaga \& Tortia, 2006; Handy \& Katz, 1998). Perhaps because of this, the nonprofit sector has higher turnover rates (Gazley, 2009), with low pay being one of the most common reasons employees cite for leaving (Nonprofit HR Solutions, 2012).

The emphasis on intrinsic motivation may also lead to greater pay equality within the sector. Wage inequality reduces job satisfaction (Card, Mas, Moretti, \& Saez, 2012). Leete (2000) argues that nonprofits pay more equitably, in part because intrinsically motivated employees care more about equity. The nonprofit sector tends to have both less wage inequality and higher job satisfaction (BenNer, Ren, \& Paulson, 2011; Leete, 2000, 2001; Preston \& Sacks, 2010).

In contrast, some argue that nonprofits pay above-market wages. Nonprofits' tax advantages allow them to be more "profitable" than their for-profit counterparts, but they cannot redistribute any surplus to their shareholders. This gives them fewer incentives to hold down costs, including wages; indeed, high wages might be a means of distributing retained earnings to important stakeholders. Furthermore, hospitals, colleges, and schools may choose to become nonprofits to build trust with consumers, and they help build trust by investing in high-quality labor.

Using data from the 2005-2013 American Community Surveys (ACS), we examine pay differences across the nonprofit, for-profit, and public sectors, focusing on registered nurses (RNs) who work for hospitals. By focusing on one large occupation within one industry (RNs working at hospitals make up 7.1\% of all nonprofit employees), we are able to eliminate most differences in the nature and conditions of work. We first examine pay difference across hospital ownership and whether differences in nurses' individual characteristics (education, age/experience, race/ethnicity, gender, and relationship status) can explain these differences. We then look at whether the nonprofit sector has smaller pay differences by race/ethnicity, gender, and relationship status. We find that nonprofit hospitals pay their nurses more, partly due to hiring more-educated, higher skilled nurses. In addition, we find little evidence that nonprofit hospitals have fewer wage disparities than public and for-profit hospitals.

\section{Does the Nonprofit Sector Pay Differently?}

Two sets of competing theories posit that the nonprofit sector pays differently than the public and for-profit sectors. Donative labor and intrinsic motivation theories argue that workers in nonprofit organizations accept lower pay because they value the good or service that they help produce (Frank, 1996; Hansmann, 1980; Leete, 2001; Preston, 1989; Rose-Ackerman, 1996). Preston (1989) argues that accepting lower wages is similar to donating money to produce a public good. Frank (1996) believes that nonprofit workers are willing to work for less because they derive more satisfaction from their work. He finds that nonprofit employees have greater job satisfaction, in part because they view their employers as more socially responsible, and that they would require a large wage premium to switch to a less socially responsible employer. Rose-Ackerman (1996) 
adds that nonprofit employees may accept lower pay when their work lines up with their idealism.

The second set of theories argues that nonprofit employees earn more, because nonprofit organizations have fewer incentives to hold down wages. A nonprofit board cannot retain profits and does not receive financial incentives to monitor how the organization's employees carry out its mission. Monitoring nonprofits' performance is more difficult because they often have complex, abstract, hard-to-quantify goals and lack the simple bottom line of profit (Ben-Ner, 2006; Steinberg, 2010). This increases nonprofit managers' discretion, which they can use to increase compensation for themselves and others. Nonprofits' tax exemptions may also lower their costs enough to allow them to afford higher quality employees (Schumacher, 2009). If education and experience do not fully capture these higher skills, empirical studies might mistakenly find a wage premium (Byrne, 2014). For instance, Holtmann and Idson (1993) find that nonprofit nursing homes pay their nurses better because they attract higher skilled nurses and provide a higher quality of service, and Preston and Sacks (2010) believe that the nonprofit wage premium in nursing care services may be due to higher quality of services. The nondistribution constraint could also explain why nurses may be more likely to donate their labor to nonprofit hospitals. Because nonprofit hospitals cannot redistribute profits to shareholders, nurses may view them more favorably and be more willing to work for them. Drevs, Tscheunlin, and Lindenmeier (2014) find that patients view German nonprofit hospitals as more trustworthy and warm although, surprisingly, less competent than for-profit hospitals.

The empirical findings are mixed. Several studies find that nonprofit employees earn less than other employees (e.g., Handy \& Katz, 1998; Lewis, 2010; Steinberg, 1990), but others find that this wage difference is due to industry differences. Ruhm and Borkoski (2003) estimate that nonprofit employees earn $11 \%$ less than comparable workers in other sectors but find the higher proportions of part-time workers and low-paying industries in the nonprofit sector almost entirely explain pay differences. Leete (2001) finds that nonprofit employees earn as much as, or more than, comparable for-profit employees. Nonprofit employees do not appear to experience a wage penalty in human services (BenNer et al., 2011; Ruhm \& Borkoski, 2003; Schumacher, 2009). Ben-Ner and Ren (2015) find that nonprofit and local government nursing homes in Minnesota pay higher wages because they delegate more decision making to their employees.

By focusing on a single occupation in a single work setting, we remove major disparities in job duties across sectors. One disadvantage of this setting is that nonprofit, public, and for-profit hospitals have similar missions, which should give nurses less motivation to donate their labor to a nonprofit hospital rather than to perform the same work at a market wage for a for-profit hospital. However, nonprofit hospitals may, in fact, take on greater social responsibility. The Congressional Budget Office ( $\mathrm{CBO}, 2006)$ estimated that even after adjusting for hospital size and location, the estimated share of uncompensated care in nonprofit hospitals was 0.6 percentage points higher than in for-profit hospitals. For-profit hospitals are more likely than public and nonprofit hospitals to provide profitable services and less likely to provide unprofitable ones (Horwitz, 
2005), and nonprofit hospitals that convert to for-profit start providing more profitable services at the expense of unprofitable ones (Cutler \& Horwitz, 2000). This may explain why volunteers are less likely to donate their time to for-profit hospitals (Wolff, Weisbrod, \& Bird, 1993). Overall, however, we see little reason for extra donative labor in nonprofit hospitals and expect that the weaker incentives to hold down wages and the stronger urge to provide quality should lead to higher pay for RNs in nonprofit hospitals. That makes hospital RNs a tough case for the donative labor theory and increases the likelihood that nonprofit hospitals' lower incentives to hold down costs will dominate.

Hypothesis 1: RNs earn more in nonprofit hospitals than in public and for-profit hospitals.

\section{Wage Inequality in the Nonprofit Sector}

Leete (2000) argues that heavy reliance on intrinsically motivated employees who highly value fairness leads nonprofits to minimize pay differences across employees. She finds race and gender pay disparities to be about one third smaller in the nonprofit sector than in the for-profit sector. Despite a slowly narrowing gender pay gap, men still earn more than women even in highly female-dominated occupations like nursing (Blau \& Kahn, 2000, 2006). Jones and Gates (2004) estimate that men earned 8\% more than women in 2000 in nursing, and Muench, Sindelar, Busch, and Buerhaus (2015) calculate an average salary gap over US\$5,000 in 2013.

Will gender pay disparities for nurses be smaller in nonprofit hospitals, as Leete (2000) suggests? Faulk, Edwards, Lewis, and McGinnis (2012) suggest that smaller gender pay gaps in the nonprofit sector may be due to the high concentration of low-paying industries and female-dominated occupations in the nonprofit sector, largely due to men accepting lower pay in female-dominated occupations in the nonprofit sector. Compensation of nurses may not follow this pattern, because nursing jobs require higher skills and pay better than most nonprofit jobs. Furthermore, if RNs in nonprofit hospitals earn as much as comparable RNs in public and for-profit hospitals, nonprofit hospitals are unlikely to have substantially more intrinsically motivated nurses or to face much stronger resistance to pay inequities than for-profit hospitals.

Ben-Ner, Ren, and Paulson(2011) pose a similar question using five human services industries (nursing homes, child care, group homes, vocational rehabilitation, and housing services) in Minnesota. They argue that for-profit firms use financial incentives more often than nonprofit or local governments and that these incentives typically create inequality. On the contrary, they cite literature showing that nonprofit managers are more intrinsically motivated (Handy, Mook, Ginieniewicz, \& Quarter, 2007; Mirvis \& Hackett, 1983) and receive lower wages (Ballou \& Weisbrod, 2003; Preyra \& Pink, 2001; Roomkin \& Weisbrod, 1999). They argue that nonprofit managers typically do not use their discretionary power to increase their own compensation, although they could, and Ben-Ner, Ren, and Paulson (2011) find smaller wage inequalities in the same occupations in nonprofit and local government organizations than in for-profit businesses. 
Although a meta-analysis of 34 studies finds that gay and bisexual men make, on average, $11 \%$ less than comparable heterosexual men (Klawitter, 2015), Lewis (2010) finds that the pay disparity is smaller in nonprofits than in government or the for-profit sector, echoing Leete's findings for gender and race pay disparities. Patterns might be different in nursing, however. Gay and bisexual men may experience wage penalties due both to the stigma of homosexuality and to their higher tendency to work in lower paid occupations with higher percentages of female co-workers (Black, Gates, Sanders, \& Taylor, 2000; Blandford, 2003; Tilcsik, 2011). Focusing on gay and straight male nurses, however, eliminates occupational differences, and straight nurses are also dealing with the widespread stereotype of male nurses as gay (Harding, 2007), suggesting that the nursing profession should be more accepting of male nurses with same-sex partners.

Hypothesis 2: Pay disparities based on gender, race/ethnicity, and relationship status may be smaller in nonprofit hospitals.

\section{Selection Into Nonprofit Hospitals}

Although our comparison of a single occupation across sectors reduces potential selection bias, some selection issues remain. However, donative labor theory suggests that the most altruistic nurses choose to work for nonprofit hospitals because they value their mission more highly and may accept lower pay to be able to do so. Alternatively, hospitals may become nonprofits to build consumer trust and may help build trust by hiring the most-qualified nurses, a strategy they can pursue because they have more surplus. Quality differences that are not captured by our education and experience measures will show up as a pay advantage rather than a higher quality workforce.

Previous scholars have dealt with selection issues in a variety of ways. Using the Current Population Survey (CPS) Outgoing Rotation Groups, Ruhm and Borkoski (2003) find that nursing and personal care workers who switch sectors (while presumably maintaining their same altruism and quality levels) see approximately the same pay effects as their cross-sectional analyses of the broader CPS predict. Using more recent years of the same data source, Schumacher (2009) gets approximately the same result, suggesting that selection effects are minor in sectoral differences in pay for nurses.

Byrne (2014) argues that the large proportion of nonprofit hospitals with religious affiliations enables him to account for self-selection, as those will attract more religious employees with altruistic motives. Using data from the 2006 CPS, he finds a similar wage premium in religious and nonreligious nonprofit hospitals. Jones (2015) argues that the nonprofit wage penalty exists primarily in industries and locations where nonprofit demand is relatively low; when an industry or location has many nonprofits, they hire all the altruistically motivated workers and must raise their wages to attract additional employees. He finds that the nonprofit wage premium is highest in industries with the largest shares of nonprofits, especially for higher educated workers (using both the $5 \%$ sample from the 2000 Census and firm-level data for nursing homes), and that the difference between nonprofit and for-profit workers in job satisfaction 
and in engagement in prosocial activities is larger in industries with fewer nonprofit employers (using the National Longitudinal Survey of Youth 1997). Given the large number of nonprofit hospitals, this is an additional reason to expect little impact of the donative labor hypothesis in this case. In sum, Ruhm and Borkoski (2003), Byrne (2014), and Jones (2015) suggest that selection bias is not a concern for our study, and Schumacher (2009) suggests that the selection bias should be very small. We perform additional sensitivity analyses, however, to ensure that selection bias does not affect our estimates.

Although Ruhm and Borkoski (2003) and Schumacher (2009) have examined nursing pay differentials across different hospital ownership, we provide a more complete and current picture. First, data from the ACS provide a much larger sample size than the Current Population Survey (especially the Outgoing Rotation Groups); our sample includes nearly 90,00o RNs, compared with about 3,000 RNs in previous studies using the CPS. Second, the nursing profession experienced a shortage between 1998 and 2006-2007 (Auerbach, Buerhaus, \& Staiger, 2007). During and after the Great Recession, a surge in the number of RNs contributed to reversing this shortage (Auerbach, Buerhaus, \& Staiger, 2011; Buerhaus, Auerbach, \& Staiger, 2009).

\section{Data and Method}

We use data from the 2005-2013 ACS. $^{1}$ We restrict our analysis to RNs who work in nonfederal hospitals. These nurses should have very similar duties across sectors, and their large numbers (nursing is the largest occupation both in the health care industry and in the nonprofit sector) allow strong comparisons of similar workers in different sectors. We restrict our sample to nurses who work full time (at least $36 \mathrm{hr}$ a week for at least 50 weeks) and are between the ages of 21 and 65. We exclude unemployed nurses and drop individuals with missing or imputed information on earnings, as Bollinger and Hirsch (2012) show that the Census Bureau's wage-imputation process implicitly assumes that all sectors pay equally. Our sample includes 89,289 RNs.

\section{Dependent Variable}

The ACS reports the wages and salaries of RNs in the past year. We convert earnings into constant 2012 dollars using the consumer price index. In our regression models, we use the natural logarithm of annual earnings as our dependent variable. This decreases the skew of the wage distribution, and most independent variables are more likely to have a constant percentage than a constant dollar impact on earnings. We dropped the top and bottom $1 \%$ of earners to eliminate misleading outliers.

\section{Sector of Employment}

We divide our RNs into three groups based on whether they report working for nonprofit, for-profit, or public hospitals. We perform most analyses separately 
for these three groups but occasionally use two dummy variables to distinguish nurses in nonprofit and public hospitals from nurses in for-profit hospitals (the reference group).

\section{Control Variables}

We include the standard control variables for earnings determination models, with slight modifications. We use six dummy variables for education, and we measure age in both years and years-squared, to capture the expected curvilinear relationship between age and compensation. We include the natural logarithm of usual hours worked per week. As gender pay disparities can differ by race, we use race and gender interaction terms (e.g., White male, White female, Black male, etc.) to examine pay disparities. We also create six interaction terms between relationship status and gender, distinguishing nurses with differentsex partners, nurses with same-sex partners, and single nurses from married nurses of the same sex (the reference group). ACS data only identify partnered gay men and lesbians, which may affect generalizability to single gay and lesbian nurses, though meta-analysis finds no evidence that estimates based in Census data overstate gay-straight differences (Klawitter, 2015). We also include sets of dummy variables to account for citizenship status, Metropolitan Statistical Area (MSA), state of employment, and year. We run separate ordinary least squares regressions models for each sector.

\section{Results}

\section{Pay Differences Between Sectors}

In 2005, the mean salaries of nurses were nearly identical in nonprofit and public hospitals but were about 5\% lower in for-profit hospitals. By 2013, mean salaries had risen about US $\$ 1,000$ in constant dollars in nonprofit hospitals and by US $\$ 2,000$ in public hospitals, but they had fallen slightly in for-profit hospitals. Thus, nonprofit earnings had fallen $1.5 \%$ below public earnings but pulled $7.2 \%$ ahead of those in the for-profit sector.

The average nurse is a White female college graduate in her 40 s. Over this period, $41 \%$ had associate's degrees, $47 \%$ had bachelor's degrees, and $11 \%$ had graduate degrees. Nursing remains an overwhelmingly female occupation: only $11 \%$ are men. Nurses are also disproportionately White and Asian; Whites and Asians make up $75 \%$ and $10 \%$ of nurses, respectively, compared with $70 \%$ and $5 \%$ of the rest of the workforce. ${ }^{2}$ Contrary to the stereotype of gay male nurses, $69.5 \%$ of male nurses are married or heterosexually partnered, compared with $69.9 \%$ of other men in the workforce. Consistent with the stereotype, however, male nurses are 5 times as likely as other employed men to have same-sex partners (2.6\% vs. $0.5 \%) .^{3}$ Nurses are as likely as other working Americans to be native-born U.S. citizens (83.5\%), but nurses are more likely than other employees with at least an associate's degree to be immigrants (15.4\% vs. $12.9 \%)$.

Patterns vary across the sectors. Over the period as a whole, nurses in public hospitals earned US $\$ 1,600$ more than nurses in nonprofit hospitals, who 
Table 1. Comparison of Nurse Compensation Across Hospital Ownership

\begin{tabular}{|c|c|c|c|}
\hline & Nonprofit & Public & For-profit \\
\hline Wage (annual) & 67,169 & 68,796 & 63,502 \\
\hline Age & $44 \cdot 5$ & 45.6 & 42.7 \\
\hline \multicolumn{4}{|l|}{ Education } \\
\hline High school or less & 0.4 & 0.5 & 0.6 \\
\hline Some college & 4.1 & 3.2 & 3.4 \\
\hline Associate degree & 36.1 & 35.4 & 42.9 \\
\hline College graduate & 46.7 & $47 \cdot 5$ & 44.1 \\
\hline Professional degree & 1.6 & 2.1 & 1.9 \\
\hline Masters & 9.6 & 11.0 & 7.0 \\
\hline $\mathrm{PhD}$ & 0.3 & 0.3 & 0.2 \\
\hline Women & 88.7 & 85.5 & 90.1 \\
\hline White & 74.6 & 52.7 & 68.8 \\
\hline Black & 4.5 & 12.4 & 7.0 \\
\hline Hispanic & 2.7 & 4.8 & 4.2 \\
\hline Asian & $5 \cdot 7$ & 13.9 & 8.9 \\
\hline Other & 1.2 & 1.7 & 1.3 \\
\hline Married & 56.7 & 53.1 & 58.1 \\
\hline Partnered & 4.1 & 3.5 & 4.6 \\
\hline Same-sex partner & 0.5 & 0.4 & 0.4 \\
\hline Unpartnered & 27.4 & 28.4 & 26.9 \\
\hline Men & 11.3 & 14.5 & 9.9 \\
\hline White & $9 \cdot 3$ & $9 \cdot 4$ & 7.2 \\
\hline Black & 0.4 & 1.5 & 0.6 \\
\hline Hispanic & 0.5 & 1.0 & 0.7 \\
\hline Asian & 0.9 & 2.3 & 1.3 \\
\hline Other & 0.2 & 0.2 & 0.2 \\
\hline Married & 8.0 & 9.6 & 6.7 \\
\hline Partnered & 0.6 & 0.6 & 0.5 \\
\hline Same-sex partner & 0.4 & 0.3 & 0.2 \\
\hline Unpartnered & 0.5 & 4.0 & 2.5 \\
\hline Noncitizen & 2.8 & 4.9 & 4.2 \\
\hline Naturalized citizen & 7.8 & 20.5 & 11.4 \\
\hline Usual hours worked & 40.9 & 41.4 & 40.8 \\
\hline Lives in an MSA & 36.8 & 40.5 & 38.0 \\
\hline Observations & 36,776 & 7,225 & 45,288 \\
\hline
\end{tabular}

MSA: Metropolitan Statistical Area.

earned US\$3,600 more than nurses in for-profit hospitals (Table 1). Nurses in for-profit hospitals were also the least experienced and educated and the least likely to be male and Asian, however, all of which could help explain their lower pay. Public hospital nurses were about 1 year older than nurses in nonprofit hospitals, who were 1.8 years older than those in for-profit hospitals. About $61 \%$ 
Table 2. Comparison of Gender and Race Composition Across Hospital Ownership.

\begin{tabular}{lrrr}
\hline & Nonprofit & Public & For-profit \\
\hline Women & & & \\
White & 84.1 & 61.7 & 76.4 \\
Black & 5.1 & 14.5 & 7.7 \\
Hispanic & 3.1 & 5.6 & 4.6 \\
Asian & 6.4 & 16.2 & 9.8 \\
Other & 1.3 & 2.0 & 1.4 \\
Married & 63.9 & 62.1 & 64.5 \\
Partnered & 4.7 & 4.1 & 5.1 \\
Same-sex partner & 0.6 & 0.5 & 0.5 \\
Unpartnered & 30.8 & 33.3 & 29.9 \\
Men & & & \\
White & 82.1 & 65.0 & 72.5 \\
Black & 3.6 & 10.5 & 5.7 \\
Hispanic & 4.4 & 7.1 & 7.0 \\
Asian & 8.3 & 16.1 & 13.0 \\
Other & 1.6 & 1.3 & 1.8 \\
Married & 70.4 & 65.7 & 67.2 \\
Partnered & 4.1 & 4.1 & 5.2 \\
Same-sex partner & 3.1 & 2.4 & 2.4 \\
Unpartnered & 22.3 & 7,225 & 25.2 \\
Observations & 36,776 & 45,288 \\
\hline
\end{tabular}

and $58 \%$ of nurses in public and nonprofit hospitals, respectively, were college graduates, compared with $53 \%$ of those in for-profit hospitals, who were also the least likely to have graduate degrees. Nurses in nonprofit hospitals were the least diverse-the most likely to be White ( $84 \%$, vs. $62 \%$ and $76 \%$ in public and for-profit hospitals) and the least likely to be immigrants (10.6\% vs. $25.4 \%$ and $15.6 \%)$. Nurses in all sectors worked similar hours weekly. We also examined whether the composition of nurses differs by gender (Table 2) and did not notice substantial differences.

Table 3 shows that location, hours worked, education, and age explain most but not all of pay differences across sectors. Race, gender, citizenship, and relationship status, however, played little role in the pay gaps. We entered the independent variables sequentially in eight separate models and tracked changes in the coefficients on public and nonprofit as we added independent variables. Thus, nurses in public and nonprofit hospitals earned $8.4 \%$ and $6.3 \%$ more than nurses in for-profit hospitals in the same year (Model 1). The pay advantages to public and nonprofit employment decrease to $5.2 \%$ and increase to $6.6 \%$, respectively, if we compare nurses working in the same state in the same year (Model 2). ${ }^{4}$ Controlling for that extra half-hour in the workweek for RNs in public hospitals shrinks their unexplained pay advantage to $4.5 \%$. Higher educational levels in public and nonprofit hospitals explains another 1.1 percentage point of 
Table 3. Nurses Pay Differences Across Sectors Compared With the For-Profit Sector.

\begin{tabular}{|c|c|c|}
\hline & Public & Nonprofit \\
\hline $\begin{array}{l}\text { Model } 1 \\
\quad \text { (Years) }\end{array}$ & $\begin{array}{l}8.4^{* *} \\
(19.6)\end{array}$ & $\begin{array}{l}6.3^{* *} \\
(26.7)\end{array}$ \\
\hline $\begin{array}{l}\text { Model } 2 \\
\quad \text { (years, states) }\end{array}$ & $\begin{array}{l}5.1^{* *} \\
(12.6)\end{array}$ & $\begin{array}{l}6.7^{* *} \\
(28.6)\end{array}$ \\
\hline $\begin{array}{l}\text { Model } 3 \\
\quad \text { (Model } 2+\log \text { hours) }\end{array}$ & $\begin{array}{l}4 \cdot 5^{* *} \\
(11.3)\end{array}$ & $\begin{array}{l}6.5^{* *} \\
(28.7)\end{array}$ \\
\hline $\begin{array}{l}\text { Model } 4 \\
\quad \text { (Model } 3+\text { education) }\end{array}$ & $\begin{array}{l}3.4^{* *} \\
(8.8)\end{array}$ & $\begin{array}{l}5 \cdot 5^{* *} \\
(24.6)\end{array}$ \\
\hline $\begin{array}{l}\text { Model } 5 \\
\quad\left(\text { Model } 4+\text { age, age }{ }^{2}\right)\end{array}$ & $\begin{array}{l}1.1^{* *} \\
(3.6)\end{array}$ & $\begin{array}{l}4.0^{* *} \\
(19.0)\end{array}$ \\
\hline $\begin{array}{l}\text { Model } 6 \\
\quad(\text { Model } 5+\text { Race } \times \text { Gender })\end{array}$ & $\begin{array}{l}1.2^{* *} \\
(3.2)\end{array}$ & $\begin{array}{l}4.0^{* *} \\
(19.0)\end{array}$ \\
\hline $\begin{array}{l}\text { Model } 7 \\
\quad \text { (Model } 6 \text { + citizenship) }\end{array}$ & $\begin{array}{l}1.1^{* *} \\
(2.9)\end{array}$ & $\begin{array}{l}4.0^{* *} \\
(19.1)\end{array}$ \\
\hline $\begin{array}{l}\text { Model } 8 \\
\quad \text { (Model } 7+\text { relationship) } \\
89,289 \text { observations }\end{array}$ & $\begin{array}{l}1.1^{* *} \\
(3.1)\end{array}$ & $\begin{array}{l}3.9^{* *} \\
(19.0)\end{array}$ \\
\hline
\end{tabular}

The coefficients reported are exponentiated and converted to percentages. $T$ statistic presented in parentheses.

${ }^{*} p<.05 ; * * p<.01$

the pay gaps, and their higher age and experience levels account for another 1.5 to 2.1 percentage points. Holding those variables constant, other characteristics (race, gender, citizenship, and relationship status) cannot explain the remaining pay gaps.

Nurses in nonprofit and public hospitals earn 3.9\% and 1.1\%, respectively, more than apparently comparable nurses in for-profit hospitals. The 2.8 percentage point pay gap between nurses in nonprofit and public hospitals is significant at the .ooo1 level. Thus, the data support our first hypothesis, that comparable nurses earn more in nonprofit hospitals.

\section{Pay Differentials by Gender, Race, and Relationship Status}

Most of the independent variables in Model 8 had the expected effects (the first column of Table 4). RNs with associate's degrees earned 6.9\% less than those with bachelor's degrees, and those with master's degrees earned an additional $15.7 \%$. Married White females earned $7.8 \%$ less than comparable married White men (very similar to the estimates of Jones and Gates, 2004). Black and Hispanic women lagged 3\% below White women, but Asian women made 5\% more. Black men earned $9 \%$ less than White men, but pay gaps for Hispanic and Asian men were much smaller.

Because of the interaction terms between gender and relationship status, the female coefficients somewhat overstate the gender pay gaps, as marital status had 


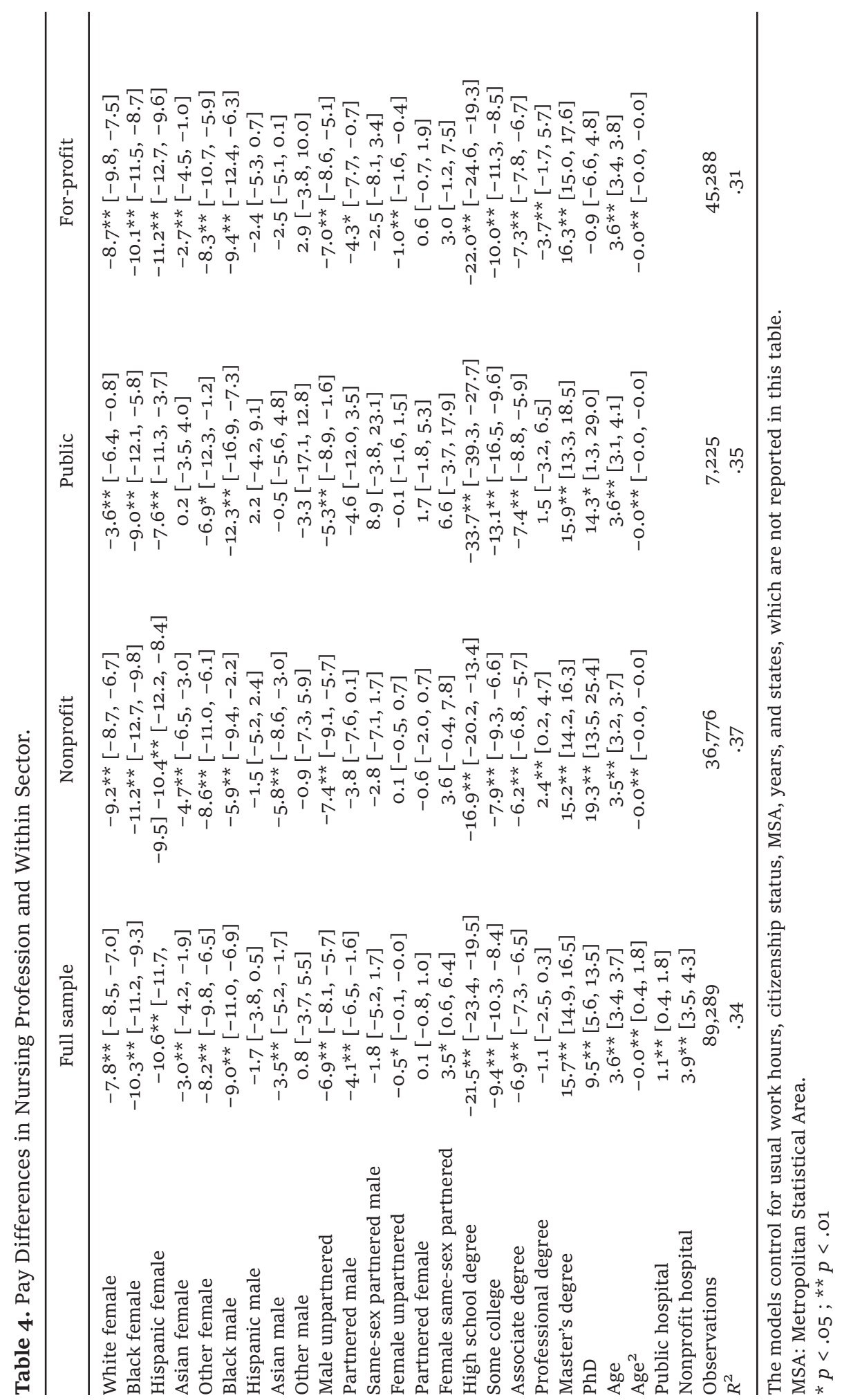


almost no impact on pay for women, but married men earned about $4 \%$ more than heterosexually partnered men and 7\% more than single men. Thus, unexplained gender pay differences are smaller for every relationship status other than married. Lesbian, gay, bisexual (LGB)-heterosexual pay differences were smaller than in most studies of the general economy (Klawitter, 2015): male nurses with male partners earned only a statistically insignificant $1.8 \%$ less than married men, and partnered lesbian nurses made $3.5 \%$ more than married female nurses.

\section{Gender, Race, and Relationship Pay Differentials Between Sectors}

The final three columns in Table 4 show separate regressions for nonprofit, public, and for-profit hospitals to test whether pay disparities are smaller in the nonprofit and public sectors. We find little evidence to support that hypothesis. As before, the reference group is married White men with bachelor's degrees, and the interaction terms complicate interpretation. The interaction terms with male are straightforward. The Black male coefficient, for instance, shows that the expected salary difference between comparable Black and White men is largest (12.3\%) in public hospitals and smallest in nonprofit hospitals (5.9\%). Asian male nurses also earn 3.5\% less than comparable White male nurses, which seems to be driven mainly by the nonprofit sector. The 95\% confidence intervals show substantial overlaps between hospital types for the other racial/ethnic groups. Likewise, although the point estimate suggests that male nurses with same-sex partners earn more than comparable married male nurses in public hospitals, none of the coefficients is statistically significant and all could vary just due to chance.

We also find a small wage premium (0.5\%) for married women (or wage penalty for single women), which is mainly driven by the for-profit sector (1\%). This is consistent with recent studies showing a wage premium for marriage (even for women; for example, Dougherty, 2006; Glauber, 2007; Killewald \& Gough, 2013), although the debate between a wage premium and penalty for married women is hardly settled (Loughran \& Zissimopoulos, 2009, for example, find a wage penalty).

The pay difference between White male and female nurses is smallest in public hospitals, but the other differences across sectors are not statistically significant. Thus, the few statistically significant differences across sectors suggest less inequality in public, but not nonprofit, hospitals except for Black male nurses, who face the highest wage penalty in public hospitals $(12.3 \%$ less than White male nurses).

\section{Sensitivity Analysis}

To test the possibility that selection effects bias our findings, we conduct additional analyses. Selection models such as Heckman (1979) or propensity score matching (e.g., Caliendo \& Kopeinig, 2008) have commonly been used to account for potential selection, but they typically rely on binary choice models (probit or logit) to estimate the probability of receiving the treatment (in our case, working for a nonprofit hospital). As our study examines three different hospital 
Table 5. Multinomial Treatment Effects Model (mtreatreg).

\begin{tabular}{|c|c|c|c|}
\hline & Public & Nonprofit & Wages \\
\hline Public & & & $\begin{array}{c}0.02 \\
(1.57)\end{array}$ \\
\hline Nonprofit & & & $\begin{array}{l}0.10 * * \\
(6.59)\end{array}$ \\
\hline Log hours & $\begin{array}{c}0.59^{* *} \\
(6.41)\end{array}$ & $\begin{array}{c}-0.15^{*} \\
(-2.26)\end{array}$ & $\begin{array}{l}0.38 * * \\
(45 \cdot 73)\end{array}$ \\
\hline Age & $\begin{array}{l}0.02 * \\
(2.05)\end{array}$ & $\begin{array}{l}0.02 * * \\
(3.29)\end{array}$ & $\begin{array}{l}\text { 0.03** } \\
(49.69)\end{array}$ \\
\hline Age-squared & $\begin{array}{c}0.00 \\
(0.28)\end{array}$ & $\begin{array}{c}-0.00 \\
(-0.43)\end{array}$ & $\begin{array}{l}-0.00 * * \\
(-38.39)\end{array}$ \\
\hline High school degree & $\begin{array}{l}-0.51^{* *} \\
(-2.64)\end{array}$ & $\begin{array}{l}-0.70 * * \\
(-5.70)\end{array}$ & $\begin{array}{l}-0.21 * * \\
(-12.28)\end{array}$ \\
\hline Some college & $\begin{array}{l}-0.27^{* *} \\
(-3.31)\end{array}$ & $\begin{array}{c}-0.09 \\
(-1.93)\end{array}$ & $\begin{array}{l}-0.08 * * \\
(-13.88)\end{array}$ \\
\hline Associate degree & $\begin{array}{l}-0.24^{* *} \\
(-7.45)\end{array}$ & $\begin{array}{l}-0.40^{* *} \\
(-20.95)\end{array}$ & $\begin{array}{l}-0.07^{\star *} \\
(-27.54)\end{array}$ \\
\hline Master's degree & $\begin{array}{l}0.34^{* *} \\
(6.77)\end{array}$ & $\begin{array}{l}0.33^{* *} \\
(10.54)\end{array}$ & $\begin{array}{l}0.14^{* * *} \\
(35.79)\end{array}$ \\
\hline Professional degree & $\begin{array}{c}-0.06 \\
(-0.61)\end{array}$ & $\begin{array}{l}-0.35^{* *} \\
(-5.40)\end{array}$ & $\begin{array}{c}-0.00 \\
(-0.19)\end{array}$ \\
\hline $\mathrm{PhD}$ & $\begin{array}{c}-0.13 \\
(-0.46)\end{array}$ & $\begin{array}{l}0.34^{*} \\
(2.07)\end{array}$ & $\begin{array}{l}0.09 * * \\
(3.88)\end{array}$ \\
\hline White female & $\begin{array}{l}-0.64^{* *} \\
(-7.54)\end{array}$ & $\begin{array}{c}-0.05 \\
(-0.90)\end{array}$ & $\begin{array}{l}-0.02 * \\
(-2.53)\end{array}$ \\
\hline Black female & $\begin{array}{l}0.20^{*} \\
(2.18)\end{array}$ & $\begin{array}{c}-0.66 * * \\
(-9.61)\end{array}$ & $\begin{array}{c}-0.03^{* *} \\
(-3.55)\end{array}$ \\
\hline Hispanic female & $\begin{array}{c}-0.15 \\
(-1.39)\end{array}$ & $\begin{array}{l}-0.53^{* *} \\
(-7.04)\end{array}$ & $\begin{array}{c}-0.04^{* *} \\
(-4.16)\end{array}$ \\
\hline Asian female & $\begin{array}{c}-0.10 \\
(-0.99)\end{array}$ & $\begin{array}{c}-0.57^{* *} \\
(-7.77)\end{array}$ & $\begin{array}{l}0.04^{* *} \\
(4.19)\end{array}$ \\
\hline Other female & $\begin{array}{c}-0.05 \\
(-0.34)\end{array}$ & $\begin{array}{l}-0.20^{*} \\
(-2.05)\end{array}$ & $\begin{array}{l}-0.03^{*} \\
(-2.49)\end{array}$ \\
\hline Black male & $\begin{array}{l}0.75^{* *} \\
(5.31)\end{array}$ & $\begin{array}{l}-0.59^{* *} \\
(-4.59)\end{array}$ & $\begin{array}{l}-0.09 * * \\
(-5.70)\end{array}$ \\
\hline Hispanic male & $\begin{array}{c}0.20 \\
(1.29)\end{array}$ & $\begin{array}{c}-0.56 * * * \\
(-4.84)\end{array}$ & $\begin{array}{c}-0.01 \\
(-0.62)\end{array}$ \\
\hline Asian male & $\begin{array}{l}0.24^{*} \\
(2.01)\end{array}$ & $\begin{array}{l}-0.51^{* *} \\
(-5.51)\end{array}$ & $\begin{array}{c}-0.03^{* *} \\
(-2.83)\end{array}$ \\
\hline Other male & $\begin{array}{c}-0.26 \\
(-0.80)\end{array}$ & $\begin{array}{c}-0.29 \\
(-1.40)\end{array}$ & $\begin{array}{c}0.01 \\
(0.26)\end{array}$ \\
\hline
\end{tabular}


Table 5. (continued)

\begin{tabular}{lccc}
\hline & Public & Nonprofit & Wages \\
\hline Noncitizen & 0.05 & $-0.28^{* *}$ & -0.01 \\
Naturalized citizen & $(0.71)$ & $(-5.26)$ & $(-1.67)$ \\
Married male & $0.34^{* *}$ & $-0.27^{* *}$ & $0.04^{* *}$ \\
Partnered male & $(6.23)$ & $(-6.62)$ & $(7.83)$ \\
& $-0.21^{*}$ & $0.14^{*}$ & $0.06^{* *}$ \\
Same-sex partnered male & $(-2.36)$ & $(2.24)$ & $(7.63)$ \\
& -0.24 & -0.05 & 0.02 \\
Married female & $(-1.20)$ & $(-0.41)$ & $(1.24)$ \\
& -0.11 & $0.35^{*}$ & 0.04 \\
Partnered female & $(-0.44)$ & $(2.07)$ & $(1.85)$ \\
Female same-sex partnered & $-0.14^{* *}$ & $-0.07^{* *}$ & -0.00 \\
Lives in a MSA & $(-4.31)$ & $(-3.53)$ & $(-0.24)$ \\
Lambda_public & -0.08 & -0.03 & -0.00 \\
Lambda_nonprofit & $(-1.04)$ & $(-0.72)$ & $(-0.11)$ \\
Observations & -0.12 & -0.03 & $0.03^{*}$ \\
\hline & $(-0.55)$ & $(-0.20)$ & $(2.06)$ \\
& $-0.18^{* *}$ & $-0.04^{*}$ & $0.05^{* *}$ \\
& $(-6.01)$ & $(-2.09)$ & $(24.86)$ \\
& -0.01 & & 89,289 \\
\hline
\end{tabular}

Excludes states and years in the selection equation. The wage model includes states and years. Robust $z$ statistics in parentheses. Log likelihood: $-91,521.163$. Log likelihood test statistic: $4.07 ; p$ $\chi^{2}(2)=.131$ (fail to reject null hypothesis of exogeneity).

MSA: Metropolitan Statistical Area

${ }^{*} p<.05 ;{ }^{* *} p<.01$

ownership types, we estimate models that account for multinomial treatment effects (Deb \& Trivedi, 2006a, 2006b). This model (Table 5) suggests that, after accounting for this selection, the wage premium for nonprofit nurses is even larger (about 10\%) and no wage differential exists between nurses working in public and for-profit hospitals. However, a likelihood-ratio test fails to reject the null hypothesis of exogenous treatment. ${ }^{5}$ We interpret this as either (a) there is no selection bias and our regression estimates provide a reliable estimate of the nonprofit (and public) wage premium for nurses, or (b) our regression estimates underestimate the actual wage premium for nonprofit nurses.

\section{Conclusion}

Contrary to donative labor and intrinsic motivation theories, we find that average nursing salaries in nonprofit hospitals are higher than in for-profit hospitals. 
This is partly because they attract more educated and experienced nurses, but they may attract those higher skilled nurses partly because they pay better. After accounting for differences in measurable characteristics (location, hours worked, education, age/experience, gender, and race), nonprofit hospitals still pay comparable nurses 3.9\% more than for-profit hospitals and $2.8 \%$ more than public hospitals. After accounting for potential selection effects using a multinomial treatment effect model, we find an even larger wage premium for nonprofit nurses (about 10\%) and no wage differential for public nurses. This wage premium over for-profit hospitals could be a result of the tax advantage of nonprofit hospitals, their potentially higher quality of service, or a combination of both. We find little evidence that nonprofit hospitals have smaller wage disparities than public and for-profit hospitals. On the contrary, pay differentials by gender, race, and relationship status appear to be as large in nonprofit as in for-profit hospitals (perhaps even larger), while public hospitals may have the smallest wage disparities.

Thus, we find no support for the donative labor hypothesis that nonprofit employees accept lower pay than they would earn in the for-profit sector to be able to do more valuable, rewarding work and nor for the argument that nonprofit employees demand greater pay equity across groups. RNs may be an especially tough case, however; as members of the caring professions, nurses can feel they are benefiting society in any type of hospital, and they may not view nonprofit hospitals as providing more valuable service than any other type of hospital. If so, they could easily prioritize pay, benefits, and hours above hospital type in choosing an employer. Alternatively, although little research compares hospital sizes, the larger average size of nonprofit hospitals could explain some of the wage premium observed. A quick back-of-the-envelope calculation using numbers reported from the Centers for Disease Control and Prevention annually shows that, on average, nonprofit hospitals have 160 beds, for-profit hospitals have 127 beds, and public hospitals have 116 beds. However, this would not explain the (small) wage premium of public nurses' relative to for-profit nurses. In addition, MSA and state of employment could already partly account for some of these differences. Regardless, we cannot rule out this possibility.

Of course, we have no information on benefits and overtime hours. State and local governments typically provide better retirement and health benefits than for-profit firms (Bender \& Heywood, 2010), with substantial variation across states (Biggs \& Richwine, 2014). We do not know whether these patterns hold for hospitals, however, but total compensation for nurses in public hospitals is probably higher relative to nurses in both nonprofit and for-profit hospitals than our estimates suggest.

Despite these limitations, the findings from this study suggest that in the nursing profession, nonprofit hospitals offer wages that are more than competitive and attract higher skilled nurses. Buerhaus, Staiger, and Auerbach (2000) argue that the RN workforce was aging and predicted a severe shortage of nurses over the following decade. These trends reversed, but the supply of nurses needs to remain steady to meet the increasing demand for health care services (Auerbach, Staiger, Muench, \& Buerhaus, 2013). As a result, hospitals are competing to hire nurses and need to provide competitive pay. This may explain why nurses see no reason to donate their labor to nonprofit hospitals and why nonprofit hospitals are compensating them more. 
Acknowledgments - The authors would like to thank three anonymous reviewers for Nonprofit and Voluntary Sector Quarterly for helpful comments.

Conflicting Interests - The authors declared no potential conflicts of interest with respect to the research, authorship, and/or publication of this article. The authors received no financial support for the research, authorship, and/or publication of this article.

\section{Notes}

1. We do not use the much smaller 2001-2004 American Community Survey (ACS) samples before the ACS was fully implemented.

2. Asians remain overrepresented in the nursing profession if we restrict the sample to those with at least an associate's degree ( $9.7 \%$ vs. $6.5 \%)$, but Whites do not ( $75.3 \%$ vs. $74.0 \%)$.

3. Female nurses are slightly less likely than other employed women to have same-sex partners (0.51\% vs. $0.67 \%)$.

4. Apparently, public hospitals tend to be concentrated in high-paying states and nonprofit hospitals in lower paying ones.

5. Deb and Trivedi (2006a) recommend using a likelihood-ratio test, which is a test for the joint hypothesis that the lambdas (public and nonprofit) are equal to o. The test compares the log-likelihood of the model where the treatment is endogenous with the one where the treatment is exogenous. In our case, we fail to reject the null hypothesis that the lambdas are 0.

\section{References}

Auerbach, D. I., Buerhaus, P. I., \& Staiger, D. O. (2007). Better late than never: Workforce supply implications of later entry into nursing. Health Affairs, 26, 178-185.

Auerbach, D. I., Buerhaus, P. I., \& Staiger, D. O. (2011). Surge in those ages 23-26 entering the registered nurse work force means that supply is growing faster than projected. Health Affairs, 30, 2286-2292.

Auerbach, D. I., Staiger, D. O., Muench, U., \& Buerhaus, P. I. (2013). The nursing workforce in an era of health care reform. New England Journal of Medicine, 368, 1470-1472.

Ballou, J. P., \& Weisbrod, B. A. (2003). Managerial rewards and the behavior of forprofit, governmental, and nonprofit organizations: Evidence from the hospital industry. Journal of Public Economics, 87, 1895-1920.

Bender, K. A., \& Heywood, J. S. (2010). Out of balance? Comparing public and private sector compensation over 20 years. Washington, DC: Center for State \& Local Government Excellence.

Ben-Ner, A. (2006). For-profit, state and non-profit: How to cut the pie among the three sectors. In J. P. Touffut (Ed.), Advancing public goods (pp.40-67). Cheltenham, UK: Edward Elgar.

Ben-Ner, A., \& Ren, T. (2015). Comparing workplace organization design based on form of ownership: Nonprofit, for-profit, and local government. Nonprofit and Voluntary Sector Quarterly, 44, 340-359. 
Ben-Ner, A., Ren, T., \& Paulson, D. F. (2011). A sectoral comparison of wage levels and wage inequality in human services industries. Nonprofit and Voluntary Sector Quarterly, 40, 608-633.

Benz, M. (2005). Not for the profit, but for the satisfaction? Evidence on worker wellbeing in non-profit firms. Kyklos, 58, 155-176.

Biggs, A. G., \& Richwine, J. (2014). Overpaid or underpaid? A state-by-state ranking of public employee compensation (Working Paper 2014-04). American Enterprise Institute for Public Policy Research.

Black, D., Gates, G., Sanders, S., \& Taylor, L. (2000). Demographics of the gay and lesbian population in the United States: Evidence from available systematic data sources. Demography, 37, 139-154.

Blandford, J. M. (2003). The Nexus of sexual orientation and gender in the determination of earnings. Industrial \& Labor Relations Review, 56, 622-642.

Blau, F. D., \& Kahn, L. M. (2000). Gender differences in pay. Journal of Economic Perspectives, 14(4), 75-99.

Blau, F. D., \& Kahn, L. M. (2006). The U.S. gender pay gap in the 1990s: Slowing convergence. Industrial \& Labor Relations Review, 6o, 45-66.

Bollinger, C. R., \& Hirsch, B. T. (2012). Is earnings nonresponse ignorable? Review of Economics and Statistics, 95, 407-416.

Borzaga, C., \& Tortia, E. (2006). Worker motivations, job satisfaction, and loyalty in public and nonprofit social services. Nonprofit and Voluntary Sector Quarterly, 35, 225-248.

Buerhaus, P. I., Auerbach, D. I., \& Staiger, D. O. (2009). The recent surge in nurse employment: Causes and implications. Health Affairs, 28, w657-w668.

Buerhaus, P. I., Staiger, D. O., \& Auerbach, D. I. (2000). Implications of an aging registered nurse workforce. Journal of the American Medical Association, 283, 2948-2954.

Byrne, P. F. (2014). Do workers profit from the nonprofit tax exemption? The impact of state tax exemption on the nonprofit wage differential of hospital workers. Public Finance Review, 42, 199-221.

Caliendo, M., \& Kopeinig, S. (2008). Some practical guidance for the implementation of propensity score matching. Journal of Economic Surveys, 22, 31-72.

Card, D., Mas, A., Moretti, E., \& Saez, E. (2012). Inequality at work: The effect of peer salaries on job satisfaction. American Economic Review, 102, 2981-3003.

Congressional Budget Office. (2006, December). Nonprofit hospitals and the provision of community benefits. Washington, DC: Author. Retrieved from http://www.cbo. gov/sites/default/files/cbofiles/ftpdocs/76xx/doc7695/12-o6-nonprofit.pdf

Cutler, D., \& Horwitz, J. (2000). Converting hospitals from not-for-profit to for-profit status: Why and what effects? In D. Cutler (Ed.), The changing hospital industry (pp. 45-78). Chicago, IL: University of Chicago Press.

Deb, P., \& Trivedi, P. K. (2006a). Maximum simulated likelihood estimation of a negative binomial regression model with multinomial endogenous treatment. Stata Journal, 6, 246-255.

Deb, P., \& Trivedi, P. K. (2006b). Specification and simulated likelihood estimation of a nonnormal treatment-outcome model with selection: Application to health care utilization. The Econometrics Journal, 9, 307-331.

Dougherty, C. (2006). The marriage earnings premium as a distributed fixed effect. Journal of Human Resources, 41, 433-443.

Drevs, F., Tscheunlin, D. K., \& Lindenmeier, J. (2014). Do patient perceptions vary with ownership status? A study of nonprofit, for-profit, and public hospital patients. Nonprofit and Voluntary Sector Quarterly, 43, 164-184. 
Faulk, L., Edwards, L. H., Lewis, G. B., \& McGinnis, J. (2012). An analysis of gender pay disparity in the nonprofit sector: An outcome of labor motivation or gendered jobs? Nonprofit and Voluntary Sector Quarterly, 42, 1268-1287.

Frank, R. H. (1996). What price the moral high ground? Southern Economic Journal, $63,1-17$.

Gazley, B. (2009). Personnel recruitment and retention in the nonprofit sector: The 21st century challenge. In S. W. Hays, R. Kearney, \& J. Coggburn (Eds.), Public personnel administration: Problems and prospects (pp. 79-92). Uppers Saddle River, NJ: Prentice Hall.

Glauber, R. (2007). Marriage and the motherhood wage penalty among African Americans, Hispanics, and Whites. Journal of Marriage and Family, 69, 951-961.

Handy, F., \& Katz, E. (1998). The wage differential between nonprofit institutions and corporations: Getting more by paying less? Journal of Comparative Economics, 26, 246-261.

Handy, F., Mook, L., Ginieniewicz, J., \& Quarter, J. (2007). The moral high ground: Perceptions of wage differentials among executive directors of Canadian nonprofits. The Philanthropist, 21, 109-127.

Hansmann, H. B. (1980). The role of nonprofit enterprise. The Yale Law Journal, 89, 835-901.

Harding, T. (2007). The construction of men who are nurses as gay. Journal of Advanced Nursing, 60, 636-644.

Heckman, J. J. (1979). Sample bias as a specification error. Econometrica, 47, 153-162.

Holtmann, A. G., \& Idson, T. L. (1993). Wage determination of registered nurses in proprietary and nonprofit nursing homes. The Journal of Human Resources, 28, 55-79.

Horwitz, J. R. (2005). Making profits and providing care: Comparing nonprofit, forprofit, and government hospitals. Health Affairs, 24, 790-801.

Jones, C. B., \& Gates, M. (2004). Gender-based wage differentials in a predominantly female profession: Observations from nursing. Economics of Education Review, 23, 615-631.

Jones, D. B. (2015). The supply and demand of motivated labor: When should we expect to see nonprofit wage gaps? Labour Economics, 32, 1-14.

Killewald, A., \& Gough, M. (2013). Does specialization explain marriage penalties and premiums? American Sociological Review, 78, 477-502.

Klawitter, M. (2015). Meta-analysis of the effects of sexual orientation on earnings. Industrial Relations: A Journal of Economy and Society, 54, 4-32.

Leete, L. (2000). Wage equity and employee motivation in nonprofit and for-profit organizations. Journal of Economic Behavior \& Organization, 43, 423-446.

Leete, L. (2001). Whither the nonprofit wage differential? Estimates from the 1990 census. Journal of Labor Economics, 19, 136-170.

Lewis, G. B. (2010). Modeling nonprofit employment: Why do so many lesbians and gay men work for nonprofit organizations? Administration \& Society, 42, 720-748.

Loughran, D. S., \& Zissimopoulos, J. M. (2009). Why wait? The effect of marriage and child-bearing on the wages of men and women. Journal of Human Resources, 44, 326-349.

Mirvis, P. H., \& Hackett, E. J. (1983). Work and work force characteristics in the nonprofit sector. Monthly Labor Review, 106(4), 3-12.

Muench, U., Sindelar, J., Busch, S. H., \& Buerhaus, P. I. (2015). Salary differences between male and female registered nurses in the United States. Journal of the American Medical Association, 313, 1265-1267. 
Nonprofit HR Solutions. (2012). Nonprofit Employment Trends Survey. Retrieved from http://www.nonprofithr.com/wp-content/uploads/2013/03/2012-EmploymentTrends-Survey-Report.pdf

Preston, A. E. (1989). The nonprofit worker in a for-profit world. Journal of Labor Economics, $7,438-463$.

Preston, A. E., \& Sacks, D. W. (2010). Nonprofit wages: Theory and evidence. In D. R. Young \& B. Seaman (Eds.), Handbook of research on nonprofit economics and management (pp. 106-119). Cheltenham, UK: Edward Elgar.

Preyra, C., \& Pink, G. (2001). Balancing incentives in the compensation contracts of nonprofit hospital CEOs. Journal of Health Economics, 20, 509-525.

Roomkin, M. J., \& Weisbrod, B. A. (1999). Managerial compensation and incentives in for-profit and nonprofit hospitals. Journal of Law, Economics, and Organization, $15,750-781$.

Rose-Ackerman, S. (1996). Altruism, nonprofits, and economic theory. Journal of Economic Literature, 34, 701-728.

Ruhm, C. J., \& Borkoski, C. (2003). Compensation in the nonprofit sector. Journal of Human Resources, XXXVIII, 992-1021.

Schumacher, E. J. (2009). Does public or not-for-profit status affect the earnings of hospital workers? Journal of Labor Research, 30, 9-34.

Steinberg, R. (1990). Labor economics and the nonprofit sector: A literature review. Nonprofit and Voluntary Sector Quarterly, 19, 151-169.

Steinberg, R. (2010). Principal-agent theory and nonprofit accountability. In K. J. Hopt \& T. Von Hippel (Eds.), Comparative corporate governance of non-profit organizations (pp. 73-126). Cambridge, UK: Cambridge University Press.

Tilcsik, A. (2011). Pride and prejudice: Employment discrimination against openly gay men in the United States. American Journal of Sociology, 117, 586-626.

Wolff, N., Weisbrod, B. A., \& Bird, E. J. (1993). The supply of volunteer labor: The case of hospitals. Nonprofit Management and Leadership, 4, 23-45.

\section{Author Biographies}

Christian King is an assistant professor of health policy in the Department of Nutrition and Health Sciences at the University of Nebraska-Lincoln. His research focuses on examining factors that contribute to social inequalities and health disparities.

Gregory B. Lewis is a professor and chair of the Department of Public Management and Policy at the Andrew Young School of Policy Studies at Georgia State University. His research has focused on career patterns of public employees, diversity issues, support for gay and lesbian rights, patterns of employment in public and nonprofit sectors, and gay-straight pay differences within sectors. 